\title{
Host Phenology and Leaf Effects on Susceptibility of California Bay Laurel to Phytophthora ramorum
}

\author{
Steven F. Johnston, Michael F. Cohen, Tamas Torok, Ross K. Meentemeyer, and Nathan E. Rank
}

First, second, and fifth authors: Department of Biology, Sonoma State University, Rohnert Park, CA 94928; third author: Lawrence Berkeley National Laboratory, Earth Sciences Division, Berkeley, CA 94720; and fourth author: Department of Forestry and Environmental Resources, North Carolina State University, Raleigh, NC 27606.

Accepted for publication 27 September 2015.

\begin{abstract}
Johnston, S. F., Cohen, M. F., Torok, T., Meentemeyer, R. K., and Rank, N. E. 2016. Host phenology and leaf effects on susceptibility of California bay laurel to Phytophthora ramorum. Phytopathology 106:47-55.

Spread of the plant pathogen Phytophthora ramorum, causal agent of the forest disease sudden oak death, is driven by a few competent hosts that support spore production from foliar lesions. The relationship between traits of a principal foliar host, California bay laurel (Umbellularia californica), and susceptibility to P. ramorum infection were investigated with multiple $P$. ramorum isolates and leaves collected from multiple trees in leaf-droplet assays. We examined whether

susceptibility varies with season, leaf age, or inoculum position. Bay laurel susceptibility was highest during spring and summer and lowest in winter. Older leaves ( $>1$ year) were more susceptible than younger ones (8 to 11 months). Susceptibility was greater at leaf tips and edges than the middle of the leaf. Leaf surfaces wiped with $70 \%$ ethanol were more susceptible to $P$. ramorum infection than untreated leaf surfaces. Our results indicate that seasonal changes in susceptibility of $U$. californica significantly influence $P$. ramorum infection levels. Thus, in addition to environmental variables such as temperature and moisture, variability in host plant susceptibility contributes to disease establishment of P. ramorum.
\end{abstract}

The generalist forest pathogen Phytophthora ramorum infects more than 130 species of plants from 34 genera and causes the emerging forest disease known as sudden oak death (SOD) in northern California (Grünwald et al. 2008; Rizzo et al. 2005). This pathogen is of great concern to foresters, land managers, and the general public because it causes widespread mortality of dominant tree species including tanoak Notholithocarpus densiflorus (Hook \& Arn.) and coast live oak Quercus agrifolia (Kelly et al. 2008; McPherson et al. 2005; Meentemeyer et al. 2004, 2008c; Metz et al. 2011). It has spread rapidly since its introduction near San Francisco Bay in the mid-1990s and now occurs across a broad geographic range in coastal California and southwest Oregon (Cushman and Meentemeyer 2008; Meentemeyer et al. 2008a, 2011). Since the discovery of $P$. ramorum as the causal agent of SOD, great efforts have been made to understand environmental and genetic factors contributing to disease establishment and to develop methods of managing its progression on tanoak and coast live oak (Frankel 2008; Goss et al. 2009; Grünwald et al. 2008; Hansen 2008; Kanaskie et al. 2009; Metz et al. 2011; Prospero et al. 2009; Rizzo et al. 2004). To a lesser extent, the primary evergreen host in California woodlands, California bay laurel (Umbellularia californica) has been studied to determine its contribution to disease prevalence (Anacker et al. 2008; Beh et al. 2012; Brown and AllenDiaz 2009; Davidson et al. 2005; DiLeo et al. 2009; Huberli et al. 2012; Kelly and Meentemeyer 2002; Meentemeyer et al. 2008b; Meshriy et al. 2006). Bay laurel has been identified as a principal source of pathogen inoculum in redwood-tanoak and mixed evergreen forests and therefore contributes greatly to disease establishment and eventually to oak mortality in a large fraction of

Corresponding author: N. E. Rank; E-mail address: rank@sonoma.edu

*The $\boldsymbol{e}$-Xtra logo stands for "electronic extra" and indicates that one supplementary table is published online.

http://dx.doi.org/10.1094/PHYTO-01-15-0016-R

(C) 2016 The American Phytopathological Society the range of the pathogen in western North America (Anacker et al. 2008; Beh et al. 2012; Cushman and Meentemeyer 2008; Davidson et al. 2008; Huberli et al. 2012; Meentemeyer et al. 2008b; Tjosvold et al. 2008).

A host plant susceptibility scale has not been constructed for $P$. ramorum as it has for plants subject to invasion by $P$. cinnamomi in Australian forests (Shearer et al. 2007). Nevertheless, field observations suggest that susceptibility of $U$. californica to $P$. ramorum is relatively low. In contrast to $N$. densiflorus, which experiences leaf lesions, twig dieback, bark cankers, and mortality, infections on $U$. californica are restricted to nonlethal foliar lesions that usually do not exceed more than one-fifth of the leaf area (Davidson et al. 2008, 2005; Denman et al. 2005). Cessation of lesion growth after initial development suggests that preformed defenses exist in $U$. californica (Goralka et al. 1996). Laboratory inoculations on $U$. californica are often unsuccessful, supporting this view (Anacker et al. 2008; Huberli et al. 2012). Paradoxically, the low susceptibility of $U$. californica contributes toward its role as principal source of inoculum in California oak woodlands because mildly infected leaves are not abscised and may serve as an inoculum reservoir in the following years (Beh et al. 2012).

In nature, $P$. ramorum requires water to release its spores, which may be dispersed to different hosts (Judelson and Blanco 2005; Ochiai et al. 2006). The climate of California limits pathogen dispersal to the rainy season, which generally lasts from November to April (Dodd et al. 2008; Fichtner et al. 2005). The host $U$. californica occurs in mixed evergreen and redwood forests of California and its seasonal growth cycle is synchronized with local climate (Huberli et al. 2012). Bud break and fruit initiation occur in February to April, when new foliage also emerges. New leaves are produced by the end of May, when rains typically cease and hot dry conditions begin. Leaf growth and maturation continues until late autumn, with most leaves fully developed by November. Initiation of late fall rains typically precedes flowering, which is usually complete by January.

This paper focuses on susceptibility of $U$. californica. Several questions emerge about features of the bay laurel and pathogen 
interaction that should be important characteristics to quantify for models of disease spread and establishment. Degree of match between host susceptibility and suitability of the environment for pathogen growth and reproduction should relate to disease establishment in nature. During wet years (e.g., 2006; Haas et al. in press), conditions should be ideal for pathogen reproduction during late fall and late winter, yet infection levels on $U$. californica foliage do not increase significantly until spring (Davidson et al. 2011). During this period, some trees do not become heavily infected until after they flower and initiate spring growth. This leads to the question of how season and the phenologic cycle of $U$. californica affect susceptibility. Another important characteristic is the proportion of leaves that are susceptible to infection while increased host susceptibility matches with pathogen activity. While monitoring trees infected across the geographical range of the pathogen, it was observed that trees infected for several years had fewer old leaves ( $>1$ year) than trees recently infected. In addition, mature leaves seemed to show more symptoms of $P$. ramorum infection than newly emerged leaves, and they were also more likely to abscise (Davidson et al. 2011). This leads to the question of how susceptibility to $P$. ramorum varies with leaf age. Another important characteristic is the area of leaf tissue susceptible to pathogen colonization. Therefore, assays were performed to determine whether all parts of a leaf were equally susceptible. Finally, $U$. californica leaves from different individual trees vary substantially with respect to indicators of microbial leaf epiphytes. By the end of summer, many leaves are covered with a sticky dark layer of sooty mold. The nature of culturable $U$. californica leaf epiphytes and the effect of their removal with an ethanol wipe on $P$. ramorum susceptibility were investigated. All of these characteristics should eventually be integrated into a deeper understanding of environmental effects on host tree characteristics and how these relate to the likelihood of pathogen success.

This research approach incorporates natural variability among host trees and among $P$. ramorum isolates collected across much of its current range in California. Prior work on P. ramorum hosts indicates considerable variation in susceptibility, which is at least partly genetically based (Anacker et al. 2008; Huberli et al. 2006, 2012; Meshriy et al. 2006). Trees used in this study were growing naturally in mixed-oak woodlands in Sonoma County. Multiple isolates of $P$. ramorum were used to avoid potential problems with lack of replication of host individual by pathogen isolate combinations. By challenging $U$. californica leaves with multiple $P$. ramorum isolates, results gain greater generality and predictive power (Abu-El Samen et al. 2003; Chen et al. 2009).

\section{MATERIALS AND METHODS}

Pathogen and host sampling. Isolates of $P$. ramorum were obtained from symptomatic leaves of the evergreen host $U$. californica sampled from 12 localities in central and northern California (Table 1, Fig. 1). Pathogen strains were isolated by embedding leaf lesions from symptomatic California bay leaves in cornmeal agar-ARP (ampicillin at $250 \mathrm{mg} \mathrm{liter}^{-1}$, rifampicin at $10 \mathrm{mg} \mathrm{liter}^{-1}$, and pimaricin at $10 \mathrm{mg} \mathrm{liter}^{-1}$ ) agar plates. Spores from resulting isolates were used to establish isogenic colonies on cornmeal agar-PARPH (ARP antibiotics plus pentachloronitrobenzene at $50 \mathrm{mg}$ liter $^{-1}$ and hymexazol at $25 \mathrm{mg} \mathrm{liter}^{-1}$ ) agar plates to inhibit fungal and oomycete contaminants. Each isolate was transferred to a V8 juice agar plate supplemented with ampicillin at $250 \mathrm{mg}$ liter-1 containing a Van Tiegham cell to remove bacterial epiphytes from hyphae (Erwin and Ribeiro 1996), which can confound assays of $P$. ramorum strain infectivity (M. Cohen, unpublished data). Axenic $P$. ramorum isolates were then transferred back onto cornmeal agar-ARP plates for use as sources for infection assays or storage. Stored isolates in subsequent assays were first used to infect leaves and reisolated using the above-mentioned method.

Leaves for susceptibility assays were sampled from mature $U$. californica individuals ( $>10 \mathrm{~cm}$ diameter breast height) growing in mixed-evergreen forests in Sonoma County. Only shade or partial shade leaves showing no visual symptoms of $P$. ramorum or other pathogens and no signs of herbivory or other physical damage were collected. This cohort of leaves had experienced one or two rainy seasons in which some leaves became infected and some were abscised. In all laboratory assays, except the leaf age experiment, only leaves from the previous emergence year were used. For example, leaves that emerged during the spring of 2011 were not used in assays until the next cohort of 2012 leaves had emerged. Detached leaves were kept in cooled plastic bags until use in laboratory assays (within $24 \mathrm{~h}$ ). For some experiments, $U$. californica trees from a site in Cloverdale, California were used. For other experiments, trees from long-term monitoring plots established by Meentemeyer and colleagues in eastern Sonoma County were used (Fig. 1, Table 1).

Susceptibility assays. An inoculum droplet method was employed to quantify leaf susceptibility to $P$. ramorum. This method estimates infection incidence rather than severity of an infection once established (Pariaud et al. 2009). The goal was to assess effect of leaf characteristics on ability of the pathogen to initiate infection. In contrast, the leaf-dip method maximizes probability of infection by immersing leaves in a suspension of pathogen propagules and quantifies changes in leaf area by measuring lesion growth (Pariaud et al. 2009; van den Berg et al. 2014). This method is analogous to the approach used by investigators studying Phytophthora spp. that infect cacao; these studies revealed that susceptibility measured by the leafdroplet method correlated well to susceptibility established by other methods (Efombagn et al. 2011; Nyassé et al. 1995; Tahi et al. 2006).

TABLE 1. Sources and sample sizes of Phytophthora ramorum isolates and Umbellularia californica trees tested ${ }^{\mathrm{a}}$

\begin{tabular}{|c|c|c|c|c|c|c|}
\hline Experiment & Isolates & Inoculum (CFU/ml) & Tree population & Number of trees & Leaves/tree & Total leaves \\
\hline \multicolumn{7}{|l|}{ Seasonal variation (July 2008-2009) } \\
\hline July 2008-June 2009 & $2,5,7,8$ & $2.7-4.0 \times 10^{4}$ & Sugarloaf Ridge State Park & 6 & $4-8$ & 492 \\
\hline July 200927 versus 15 months & $2,5,7,8$ & $2.4-5.6 \times 10^{4}$ & Sugarloaf Ridge State Park & 6 & 8 & 48 \\
\hline Winter (Dec. 2007) 20 versus 8 months & $1,5,6$ & $2.0-23.0 \times 10^{4}$ & Cloverdale & 6 & 6 & 36 \\
\hline Spring (Mar. 2012) 23 versus 11 months & $9,10,12$ & $3.5-6.4 \times 10^{4}$ & Cloverdale & 6 & 12 & 72 \\
\hline \multicolumn{7}{|l|}{ Effect of inoculum position } \\
\hline Fall (Sep. 2008) & 5 & $1.0 \times 10^{4}$ & Sugarloaf Ridge State Park & 9 & 2 & 109 \\
\hline Spring (Apr. 2012) & $5,10,12$ & $1.8-4.1 \times 10^{4}$ & Cloverdale & 8 & 6 & 48 \\
\hline Winter (Dec. 2012) & $9,11,12$ & $0.2-4.1 \times 10^{4}$ & Fairfield Osborn Preserve & 8 & 6 & 48 \\
\hline Epiphytic fungi on bay laurel & NA & NA & Annadel & 23 & 6 & 138 \\
\hline
\end{tabular}

${ }^{a}$ Isolates were collected within the contiguous range of the pathogen and test trees were located in woodland plots in Sonoma County, California in June 2007* or April 2010**: Big Sur (1 and 2)*, Santa Cruz (3)*, Boulder Creek State Park (4)*, Castle Rock State Park (5)*, Mill Valley (6 and 7)*, Petaluma (8)*, Sebastopol $(9)^{*}$, Annadel State Park (10)**, Jack London State Park (11)*, and Kenwood (12)**. 
For each detached leaf assay, clear plastic boxes with opaque lids $(15 \times 30 \times 11 \mathrm{~cm})$ were filled with a bed of vermiculite (1 liter) moistened with de-ionized water $(450 \mathrm{ml})$. Leaves were placed abaxial side up and inoculated with six 10- $\mu$ l droplets of encysted zoospores of $P$. ramorum. For most experiments, droplets were placed midway between the midvein and leaf margin (Fig. 2A), except for the inoculum position experiment (Fig. 2B). Average diameter of droplets remained stable throughout experiments $($ mean $=$ $3.44 \pm 0.0 .13 \mathrm{~mm}, n=6$ leaves). One control leaf (with 10- $\mu$ l droplets of sterile water) and 6 to 12 test leaves were placed into each box in random order. Control leaves never produced a lesion. Because microscopic counts estimate number of spores but not the number of viable spores (Davidson et al. 2002), a most probable number (MPN) V8 juice agar plating procedure was used to estimate colony forming unit (CFU) density for each isolate zoospore suspension (Alexander 1982). Spore numbers were standardized among isolates by diluting the spore preparation to 4 to $5 \times 10^{5}$ spores $\mathrm{ml}^{-1}$ and determining MPN value (Table 1). After leaf inoculation, the boxes were incubated at $20^{\circ} \mathrm{C}$ for 7 days. At the end of this period, leaf susceptibility was measured by scoring severity of $P$. ramorum infections (Johnston 2009). A single point lesion was scored as a one. Close examination of the axial leaf surface under a dissecting microscope was used to confirm that the lesion penetrated the leaf. Two or more point lesions were scored as a two, and a spot lesion covering part of the inoculum droplet area was scored as a three. These lesions were irregular and usually delimited by small veins within the leaf. A spot completely covering the inoculation site was scored as a four. A lesion spreading beyond the boundary of the inoculum droplet was scored as a five. In all experiments, two replicate boxes were prepared for each treatment combination. To assure that lesions that formed during experiments were caused by $P$. ramorum rather than another pathogen, leaf tissue was excised from six randomly selected infection sites of each isolate and reisolated the pathogen by embedding in PARPH plates. In every case, this procedure confirmed $P$. ramorum.

To analyze data, means of the leaf infection score described above were calculated. This generated an interval level variable with an underlying normally distributed error variable, allowing us to adopt parametric statistical analyses of the data (Nyassé et al. 1995). A mixed model repeated-measures analyses was conducted to analyze average infection score. Box was specified as subject for mixed models analyses, and "box" and "tree" were specified as random effects. In all analyses, tree was also specified as a repeated factor because one leaf from each tree was included in each box. This allowed incorporation of box as a blocking factor. For some analyses, multiple treatments were applied to each leaf and these included nested within-subjects factors (Moser 2004). To identify the best model, the best covariance structure was determined by comparing Akaike information criterion (AIC) values for typical covariance structures: unstructured, autoregressive, and compound symmetry (with or without heterogeneous variances). The covariance structure with the lowest AIC value was selected before comparing the 'full' saturated model with all main effects and interaction terms to reduced models using the maximum likelihood option (ML) in SAS version 9.2 (Kinkaid 2005; Littell et al. 1998). The overall model with the lowest AIC value was selected and run using the restricted maximum likelihood option (REML in SAS) to test fixed effects and interactions. Residuals from all final models were normally distributed, indicating that the scoring
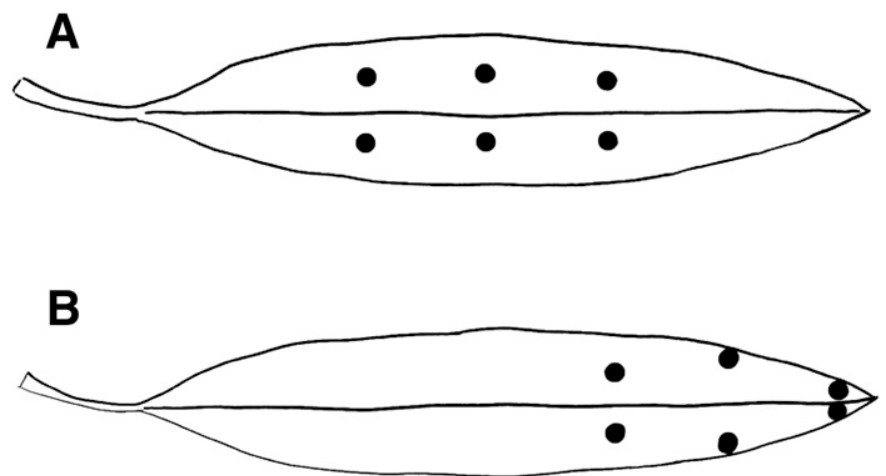

Fig. 2. Arrangement of six inoculum droplets onto Umbellularia californica leaves to quantify susceptibility. A, Configuration used for all experiments except for those to quantify effects of inoculum position. B, Arrangement used to quantify effects of inoculum position. Droplets were positioned far enough from the tip that the leaf midvein prevented them from merging.

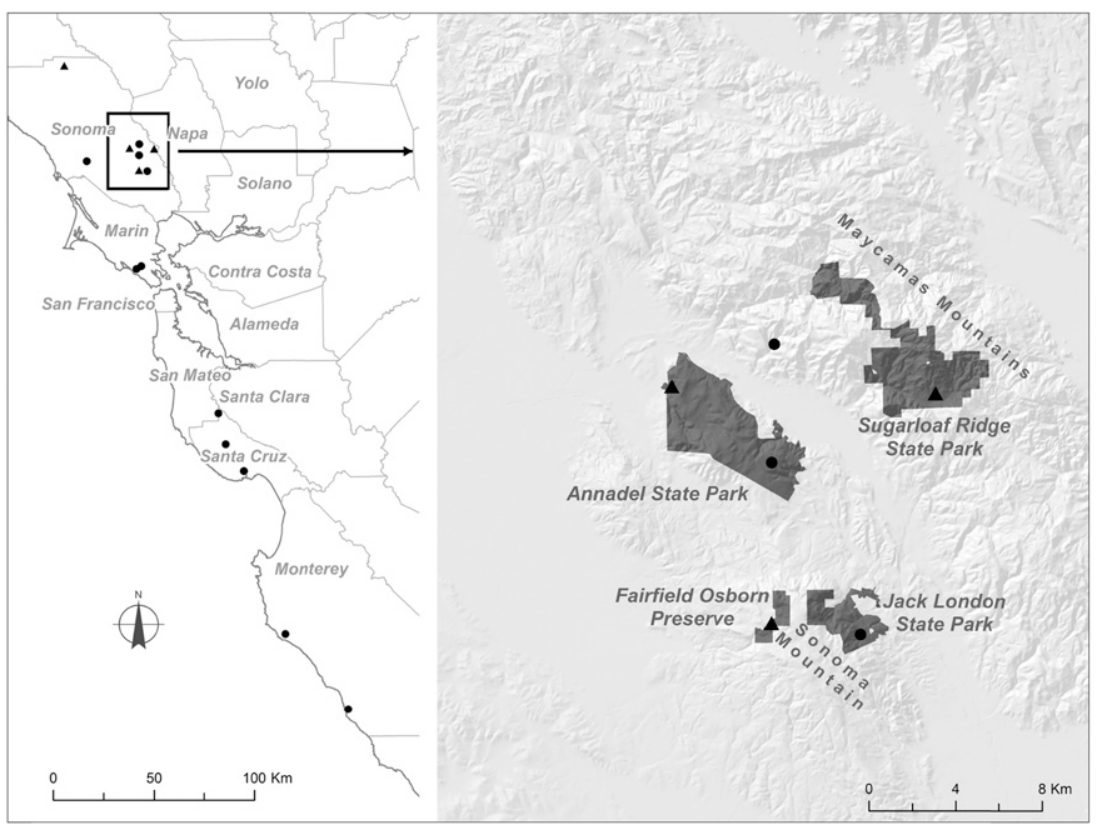

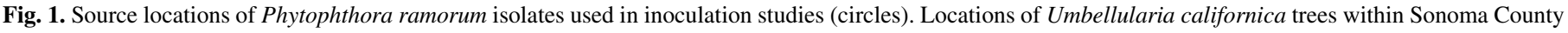
from which leaves were sampled for laboratory experiments are shown (triangles). 
system described above yielded an interval level response variable with even differences among scores.

Seasonal variation in susceptibility. The susceptibility of six $U$. californica trees to multiple $P$. ramorum isolates was quantified each month between July 2008 and June 2009 (Table 1). Isolates were selected based on geographic source and variation in infectivity as observed in previous laboratory assays. For each isolate, two boxes were set up with one leaf per tree $(n=6$ inoculated leaves and one control leaf). Number of isolates per month varied because of differences in suitability for spore production. Leaves produced during spring 2007, hereafter referred to as the emergence year, were used throughout the study while they aged (15 months in 2008 to 26 months in June 2009). These data were analyzed using month and isolate as fixed effects, and box, tree, and the interaction between tree by isolate and tree by month as random effects. The final model included fixed effects of month and isolate and random effects, with a first order autoregressive covariance structure and heterogeneous variance ( $\operatorname{arh}(1)$ in SAS). In June 2009, we compared 2007 with 2008 leaves (Table 1). These data were analyzed using the fixed main effects of leaf age and isolate and random effects of tree and box, with an autoregressive covariance structure $(\operatorname{ar}(1)$ in SAS).

Relationship between leaf age and susceptibility. Two comparisons of effect of leaf age on susceptibility were made. The same 6 trees were used in both experiments, but different isolates were used. In each experiment, mature leaves from the prior emergence year were compared with leaves that were 1 year older (Table 1). In the first experiment (December 2007), seven leaves (six tests, one control) of both age classes were placed into each box, and six boxes were used (two per isolate). In the second experiment (March 2012), 13 leaves (12 test, one control) of both age classes were placed into each box. With two boxes per isolate, this resulted in twice as many leaves as in the first experiment (Table 1). The Cloverdale locality, where $P$. ramorum was not present (in 2007), was chosen for the first experiment to avoid loss of leaves from the sampling pool due to infection or abscission during the rainy season. By the time of the second assay in 2012, P. ramorum was present in Cloverdale and both emergence cohorts had lost some leaves to infections and abscissions. To analyze both experiments, models including leaf age, isolate, and the interaction (fixed effects), and the random effects of tree and tree by age were evaluated. The first experiment included a single within subjects factor (tree) and the best covariance structure was compound symmetry. The second experiment included two within-subjects factors (tree and leaf age) and the best covariance structure was unstructured and compound symmetry (type=un@cs in SAS).

The relationship between leaf age and evidence of $P$. ramorum infection for naturally growing trees was also measured. In March 2012, the number of $P$. ramorum-symptomatic leaves was counted for 1- to 4-year-old leaves along two branches per tree for 23 U. californica trees in eight localities in Annadel State Park (Fig. 1). To determine age of leaves, leaves were carefully examined with respect to position of bud scars, leaf shape and tree architecture. A mixed model with the fixed effect of leaf age and random effects of locality, tree nested in locality and interactions with leaf age (covariance structure $=\operatorname{arh}(1)$ in SAS) was used to determine whether proportion of symptomatic leaves increased with age using Before analysis; the proportion of leaves was square-root transformed to satisfy assumptions of parametric statistics.

Effect of inoculum position on leaf susceptibility. For these experiments, the susceptibility of the tip, margin, and middle of the leaf near the midvein was quantified (Fig. 2B). Nine (first experiment) or eight (second experiment) inoculated leaves from different trees were included in each box, and two boxes were tested. In the first experiment, only one $P$. ramorum isolate was tested, but in the second experiment three isolates were tested (Table 1). Before analysis, the mean infection score of two droplets per leaf position was calculated. Both experiments were analyzed as repeated measures designs with fixed effect of inoculum position and random effects of tree, box, and interactions with inoculum position. Analysis of the second experiment tested for interactions between isolate and position and random effects. The final analysis included tree and inoculum position as within-subjects factors (type=un@cs in SAS).

Effect of ethanolic leaf wipe on susceptibility. To quantify the effect of surface microorganisms on $U$. californica leaf susceptibility, one half of each leaf, delimited by the midvein, was gently wiped with $70 \%$ ethanol, while the other leaf half was left as a control. Eight leaves were included in each box and two
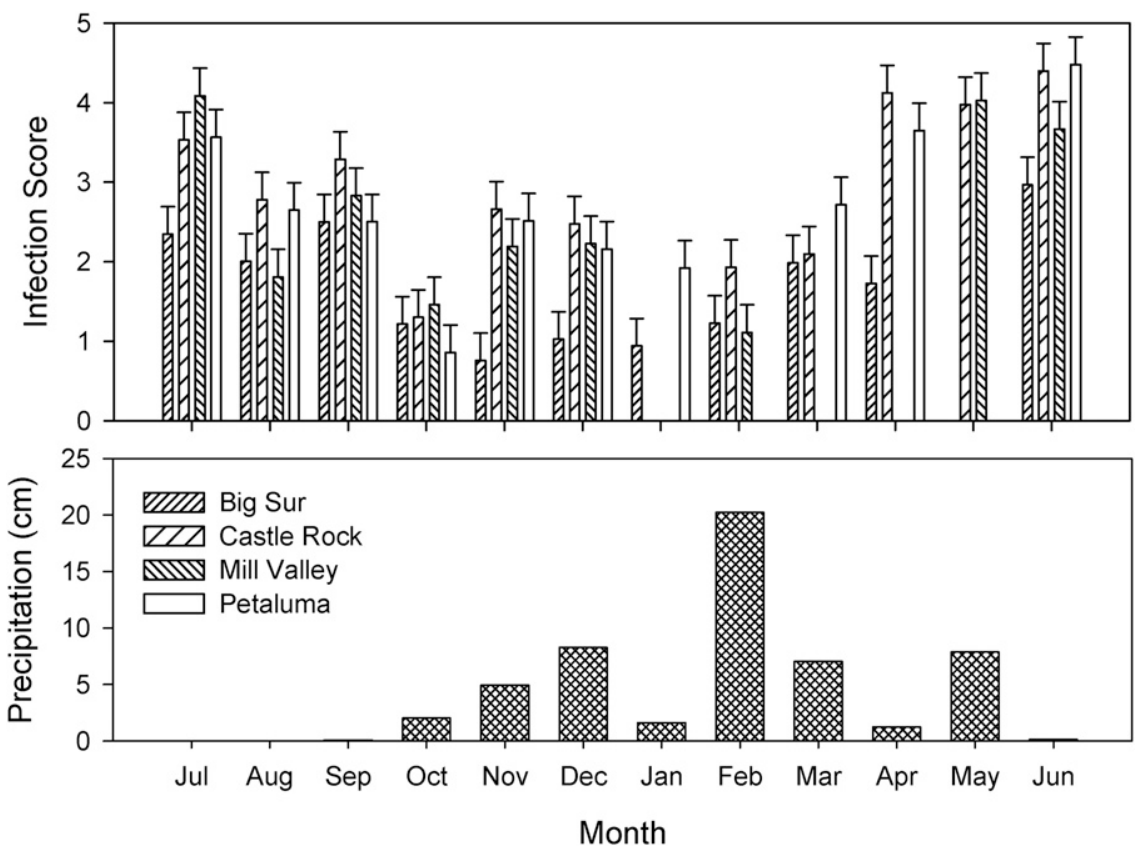

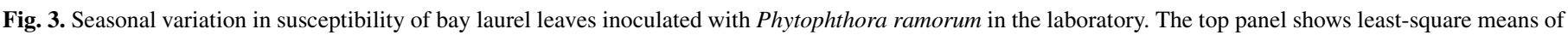

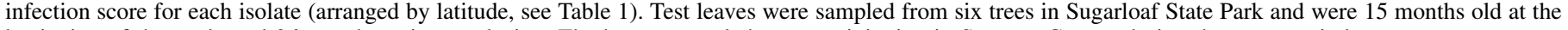
beginning of the study and 26 months at its conclusion. The bottom panel shows precipitation in Sonoma County during the same period. 
boxes were used for each combination of tree and isolate. These data were analyzed using a repeated measures design with isolate, treatment, and their interactions as fixed effects, tree and its interactions with isolate and treatment as random effects, and two within-subjects factors of tree and leaf treatment (control versus removal; type=un@cs in SAS).

Fungal isolates from $\boldsymbol{U}$. californica leaves. Leaves from 23 $U$. californica trees from eight sites in Annadel State Park were assayed for identification of epiphytic fungi. Leaves were divided at the midvein and the area of one half measured using NIH ImageJ (version 1.440), and the other half discarded. The retained half leaves were cut into 10 approximately equal pieces and placed in a $50-\mathrm{ml}$ Falcon tube containing $25 \mathrm{ml}$ of $0.1 \%$ sterile peptone solution. After mild vortexing, duplicate plates of 1/10th-strength PDA supplemented with chloramphenicol at $13 \mathrm{mg} \mathrm{liter}^{-1}$ and ampicillin at $100 \mathrm{mg} \mathrm{liter}^{-1}$ were spread with $0.1 \mathrm{ml}$ of $10^{-1}$ dilution of the peptone suspension from each tree. Plates were incubated at $28^{\circ} \mathrm{C}$ for 7 days. The array of fungal colonies was surveyed and the eight most prevalent morphotypes were isolated for sequence-based identification.

Genomic DNA was extracted with the DNA-EZ kit (GeneRite, North Brunswick, NJ) and an $\sim 1.5$-kb fragment encompassing part of the $18 \mathrm{~S}$, the entire internal transcribed spacer 1 (ITS-1), 5.8S, ITS-2, and the $5^{\prime}$ end of the $28 \mathrm{~S}$ gene was polymerase chain reaction (PCR)-amplified using TaKaRa reagents (TaKaRa, Mountain View, CA) and the primers ITS1F (Lai et al. 2007) and TW13 (Taylor and Bruns 1999). The amplicons were purified with the QIAquick PCR Purification Kit (Qiagen, Valencia, CA) and bidirectionally sequenced at the UC Berkeley DNA Sequencing Facility. The returned sequences were edited using the 4Peak software package (http://nucleobytes.com/4peaks/) and aligned with Clustal Omega (http://www.ebi.ac.uk/Tools/msa/clustalo/). The consensus sequence was then submitted to the NCBI nucleotide database (http:// blast.ncbi.nlm.nih.gov/Blast.cgi) to find the best match based on sequence identity scores and gene coverage.

\section{RESULTS}

Seasonal variation in leaf susceptibility. $U$. californica leaf susceptibility declined from late summer through the fall and winter months before peaking in late spring (Fig. 3). Variation among months and isolates was highly significant (months $F_{11,65.6}=9.9$, $P<0.0001$; isolates $\left.F_{3,23.9}=17.5, P<0.0001\right)$. Susceptibility was high in June 2009 (Fig. 3), but was greater for 2007 leaves than for 2008 leaves $\left(F_{1,10.2}=4.3, P=0.06\right)$.

Relationship between leaf age and susceptibility. In the first experiment, susceptibility of leaves from the prior emergence year was greater than the current emergence year (Fig. 4A; $F_{1,5}=$ $43.8, P=0.0012)$. Susceptibility of older leaves was greater than younger leaves in the second experiment (Fig. $4 \mathrm{~B} ; F_{1,3.3}=47.2, P<$ $0.005)$. In the field survey, proportion of symptomatic leaves increased steadily as leaves aged (Fig. $5 ; F_{3,16.4}=85.4, P<0.0001$ ).

Effect of inoculum position on leaf susceptibility. Susceptibility was greater at leaf edges than near the center of the leaf and it was greatest at the leaf tip (Fig. 6A and B). This pattern was strikingly similar for both experiments, even though they were conducted using different trees, mostly different isolates, and at a different time of year (Table 1). This effect was not significant in the first experiment $\left(F_{2,2}=2.1, P=0.32\right)$, but highly significant in the second one $\left(F_{2,6.9}=33.8, P<0.001\right)$.

Effect of leaf epiphyte removal on susceptibility. In both experiments, leaf surfaces wiped with $70 \%$ ethanol were more susceptible to $P$. ramorum infection than untreated leaf surfaces (Fig. 7A and B; first experiment $F_{1,7.4}=32.8, P<0.001$, second experiment $F_{1,6.9}=53.9, P<0.001$ ). The eight most common fungal colony types isolated from rinses of cut $U$. californica leaf fragments were identified and the majority were found to have closest matching sequence identity to strains in the NCBI database

possessing biocidal activity (Supplementary Table S1). Antagonism toward $P$. ramorum by these isolates was not further investigated.

\section{DISCUSSION}

It is widely recognized that host susceptibility and favorable environmental conditions play a critical role in the progression of forest epidemics (Anacker et al. 2008; Cobb et al. 2010; Huberli et al. 2012; Vaclavik et al. 2010). Ecological impact of an invasive pathogen may be greatest when conditions favoring pathogen reproduction coincide with heightened susceptibility of hosts. Disease spread of $P$. ramorum occurs during California's rainy season, which typically extends from November to April (Rizzo et al. 2002a, b). Paradoxically, P. ramorum inoculum load does not increase during the wettest months even when temperatures are suitable, but rather in late spring (Davidson et al. 2005).

An inoculum droplet method was used to quantify leaf susceptibility to $P$. ramorum to assess the effect of leaf characteristics on ability of the pathogen to initiate infection. In the seasonality study, an increase in susceptibility of $U$. californica to $P$. ramorum from winter to early summer was observed. Susceptibility was lowest during winter months but increased rapidly during spring, concurrent with the natural increase in inoculum load. While these findings are consistent with the timing of precipitation being essential for sporulation, results also suggest that bay laurel physiological condition plays a greater role in transmission of $P$. ramorum than is generally recognized. Huberli et al. (2012) obtained a similar pattern when testing a greater number of trees against one $P$. ramorum isolate and measuring disease severity.

We predict that disease prevalence will be more severe when rains continue into late spring not only because temperatures are warmer, but also because $U$. californica susceptibility in this study continued to increase until June. In contrast, when rains cease before host susceptibility increases, it is expected that disease levels remain low. This is consistent with observations during recent wet and dry years, especially the short rainy seasons of 2012 and 2013. June rainfall in California, though rare, may lead to high inoculum loads and a substantial increase in infection of tanoak and coast live oak (Davidson et al. 2008, 2011, 2005).

The field observation that older leaves seemed to be more infected than younger ones was supported in the laboratory and in the field. Older $U$. californica leaves were found to be more

A December 2007

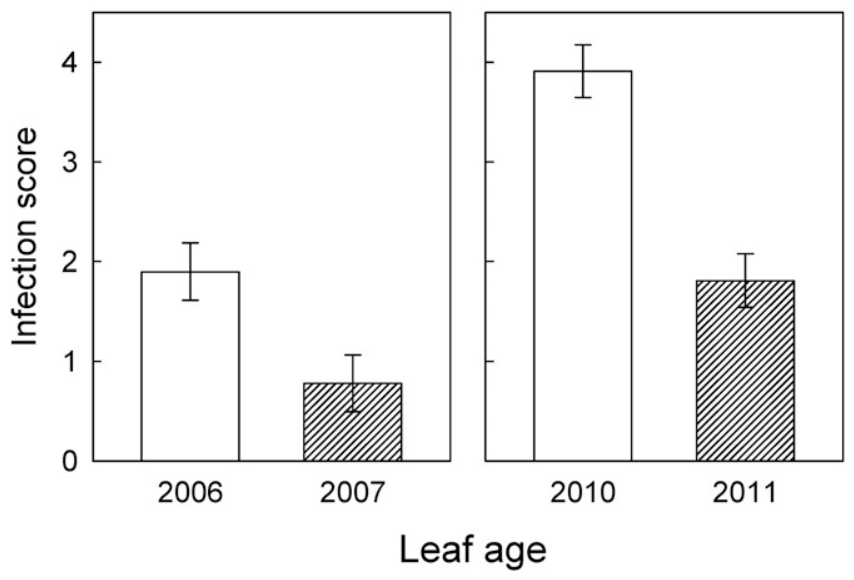

Fig. 4. Effect of leaf age on susceptibility. A, Comparison of 20- versus 8month-old leaves from six trees from Cloverdale in December 2007. B, Comparison of 23- versus 11-month-old leaves from the same trees in March 2012 (isolates are shown in Table 1). 
susceptible to $P$. ramorum than younger ones. This was true in the winter, spring, and fall. Some leaves that had been exposed to rainwater inoculum during winter months were lost to abscission. Some infections counted during the field survey may have been caused by organisms other than $P$. ramorum, yet field counts only included lesions that were morphologically similar to those that produce $P$. ramorum cultures in the laboratory. The presence of other Phytophthora species in the survey area is known to be very low (DiLeo et al. 2014). The large late spring increase in susceptibility demonstrated in the study of seasonal variability was probably not driven by leaf age alone since the susceptibility of this cohort decreased in fall, despite increased susceptibility due to leaf aging. Increased symptoms of $P$. ramorum infection on older leaves in nature support this observation and indicate that the likelihood of infection rises with leaf age. This pattern appears to reverse when examining juvenile leaves. For example, Hansen et al. (2005) found that 1-month-old leaves of Oregon populations of $U$. californica showed more lesion growth than older ones. Increases in susceptibility with

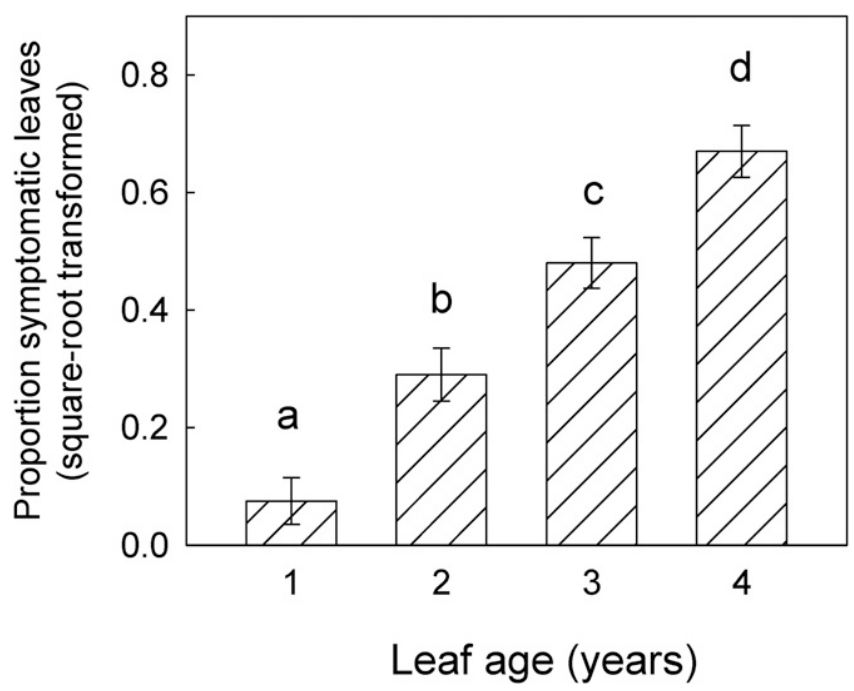

Fig. 5. Relationship between leaf age and proportion of symptomatic leaves in the field. Data from 23 trees growing in eight plots in Annadel State Park $(n=$ 1,096 first, $n=1,260$ second, $n=679$ third, and $n=207$ fourth year leaves). Data shown are least squares means, weighted by number of leaves in each age class. Letters indicate significantly different means based on SMM multiple comparisons tests using adjusted degrees of freedom in PROC MIXED.

\section{A Sugarloaf Ridge}

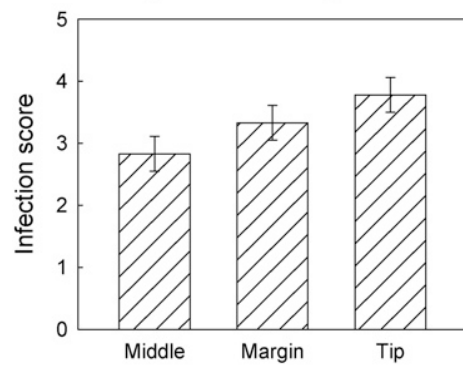

B Cloverdale

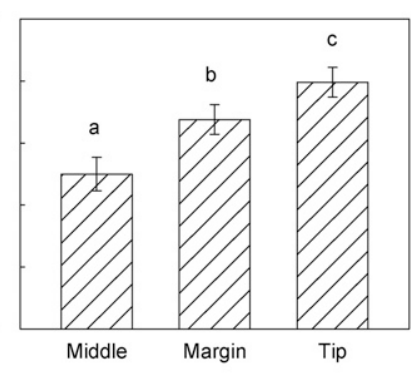

Inoculum position

Fig. 6. Relationship between inoculum position and susceptibility for leaves on trees from two localities. Arrangement of inoculation droplets is shown in Figure 2B. A, Results from nine trees from Sugarloaf Ridge State Park inoculated with zoospores from one Phytophthora ramorum isolate. B, Results from eight trees from Cloverdale inoculated with zoospores from three $P$. ramorum isolates (Table 1). Different letters indicate significantly different means based on SMM multiple comparisons tests.

leaf age have been observed in other pathosystems, including Phytophthora species (De Dobbelaere et al. 2010; Tahi et al. 2006). One implication of this finding is that the inherent resistance of mature leaves decreases over time, allowing minor infections to persist in leaf tissue until the leaf is abscised. Analyses of $U$. californica leaf secondary chemistry suggest that some compounds decline with increasing leaf age (Goralka et al. 1996); these compounds may play a role in reduced infection of young mature leaves. Alternatively, phenological changes in leaf quality to the pathogen may occur as leaves age. At the stand level, persistence of the pathogen among years may depend on the presence of low-level infection in older $U$. californica leaves.

Position of inoculum on the leaf blade also affected susceptibility. Previous observations of frequent infections on leaf tips and margins attributed to pooling rainwater inoculum in these locations are supported by measurements of their susceptibility in the laboratory (Anacker et al. 2008; Condeso and Meentemeyer 2007; Davidson et al. 2008, 2005; Meentemeyer et al. 2008b). The combination of higher susceptibility and concentration of spores in water droplets suspended on leaf tips and margins probably interact to produce the observed pattern.

The increased susceptibility to infection detected in $70 \%$ ethanoltreated leaf areas could indicate a protective role for epiphytic microorganisms, or increased susceptibility due to changes in leaf surface caused by the ethanol wipe; further experiments would be needed to directly measure the contribution to resistance, if any, by epiphytes (Widmer and Dodge 2013). The contribution of naturally occurring epiphytic fungi to resisting Phytophthora spp. has been noted in other plant species (Hoopen et al. 2003; Kharwar et al. 2010), but this has not been previously reported for hosts of P. ramorum. The majority of the closest NCBI database matches for the isolated fungi have been shown to display antagonism toward phytopathogens.

These results also suggest a practical application that may help suppress inoculum buildup in California woodlands: removal of mature $U$. californica leaves before the pathogen grows and produces inoculum. This could be accomplished by an application of a chemical defoliant at the appropriate time of year. Such an approach may not be sufficient to prevent the spread of the pathogen

\section{A Cloverdale}

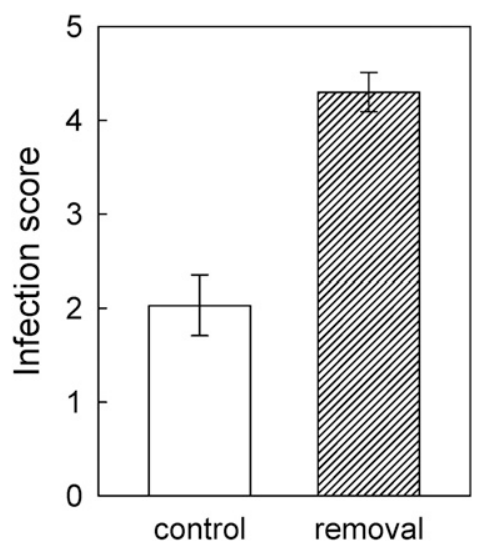

\section{Leaf wipe treatment}

Fig. 7. Effect of ethanolic wipe on leaf susceptibility. A, Results from eight trees from Cloverdale inoculated with zoospores from three Phytophthora ramorum isolates. B, Results from eight trees from Fairfield Osborn Preserve inoculated with zoospores from three $P$. ramorum isolates (Table 1). The treated half of each leaf was wiped once with $70 \%$ ethanol prior to inoculation, while the control half was left undisturbed. 
or to remove it, but possibly might slow the progression of oak mortality in some circumstances.

$P$. ramorum has killed millions of trees belonging to ecologically and economically important tree species in California woodlands (Garbelotto and Hayden 2012; Metz et al. 2012; Ramage et al. 2012). Research efforts have focused primarily on important questions about epidemiology (Cooke 2007; Filipe et al. 2012; Hansen et al. 2008; Mascheretti et al. 2009; Prospero et al. 2007; Rizzo 2006), forest management (Frankel 2008; Garbelotto and Schmidt 2009; Grünwald et al. 2008; Kovacs et al. 2011; Metz et al. 2011; Rizzo 2006; Rizzo et al. 2004; Vaclavik et al. 2010), and ecological consequences of the invasion (Brown and Allen-Diaz 2009; McPherson et al. 2010; Meentemeyer et al. 2008b,c; Vaclavik et al. 2010). Further insights may be gained by developing a greater understanding of the mechanisms of infection, especially of foliar hosts that serve as inoculum reservoirs to economically important canker hosts. Many studies in agricultural systems have documented similar influences of plant growth physiology (Grünwald and Flier 2005; Thaler et al. 2004), damage to susceptible tissues (Bae et al. 2008; Bouwmeester and Govers 2009; Le Berre et al. 2008; Tian and Babadoost 2004), and microbial associates of hosts on susceptibility to Phytophthora species (Bhadauria et al. 2010; Brown and Tellier 2011; Ottmann et al. 2009). The studies have also revealed that plants possess active defense mechanisms to promote resistance (Colas et al. 2001; Gebhardt and Valkonen 2001; Huitema et al. 2004; Huitema et al. 2005; Kamoun et al. 1993; Liu et al. 2005; Soanes and Talbot 2008; Tyler 2002). Results of this study offer evidence of similar processes in forest ecosystems. An understanding of these processes is essential for standardizing methods to assess $P$. ramorum infectivity and host susceptibility and may help guide development of methods to limit establishment of $P$. ramorum in oak woodlands.

\section{ACKNOWLEDGMENTS}

We thank the following individuals for their assistance with this work. E. Fichtner and K. Aram from the Rizzo lab at UC-Davis provided insights into culturing and infectivity assay methodology. Sonoma State University students J. Embree, C. Windsor, and E. Yamamoto helped with laboratory work. Discussions with F. Lavoipierre, W. Dillon, and B. Anacker helped situate the study within "the big picture" and W. Dillon made the map. S. Schumacher provided valuable support and inspiration. This manuscript was improved greatly by comments by two anonymous reviewers and the Phytopathology editor. We gratefully acknowledge financial support from the United States Department of Agriculture Forest Service, Pacific Southwest Research Station and Northern California Botanists.

\section{LITERATURE CITED}

Abu-El Samen, F. M., Secor, G. A., and Gudmestad, N. C. 2003. Variability in virulence among asexual progenies of Phytophthora infestans. Phytopathology 93:293-304.

Alexander, M. 1982. Most probable number method for microbial populations. Pages 815-820 in: Methods of Soil Analysis, Part 2. A. L. Page, R. H. Miller, and D. R. Keeny, eds. American Society of Agronomy, Madison, WI.

Anacker, B. L., Rank, N. E., Huberli, D., Garbelotto, M., Gordon, S., Harnik, T., Whitkus, R., and Meentemeyer, R. 2008. Susceptibility to Phytophthora ramorum in a key infectious host: Landscape variation in host genotype, host phenotype, and environmental factors. New Phytol. 177:756-766.

Bae, H., Kim, S. H., Kim, M. S., Sicher, R. C., Lary, D., Strem, M. D., Natarajan, S., and Bailey, B. A. 2008. The drought response of Theobroma cacao (cacao) and the regulation of genes involved in polyamine biosynthesis by drought and other stresses. Plant Physiol. Biochem. 46:174188.

Beh, M. M., Metz, M. R., Frangioso, K. M., and Rizzo, D. M. 2012. The key host for an invasive forest pathogen also facilitates the pathogen's survival of wildfire in California forests. New Phytol. 196:1145-1154.

Bhadauria, V., Banniza, S., Wang, L. X., Wei, Y. D., and Peng, Y. L. 2010. Proteomic studies of phytopathogenic fungi, oomycetes and their interactions with hosts. Eur. J. Plant Pathol. 126:81-95.
Bouwmeester, K., and Govers, F. 2009. A novel method for efficient and abundant production of Phytophthora brassicae zoospores on Brussels sprout leaf discs. BMC Plant Biol. 9:111.

Brown, J. K. M., and Tellier, A. 2011. Plant-parasite coevolution: Bridging the gap between genetics and ecology. N. K. VanAlfen, G. Bruening, and J. E. Leach, eds. Annu. Rev. Phytopathol. 49:345-367.

Brown, L. B., and Allen-Diaz, B. 2009. Forest stand dynamics and sudden oak death: Mortality in mixed-evergreen forests dominated by coast live oak. For. Ecol. Manage. 257:1271-1280.

Chen, C. Q., Huang, L. L., Buchenauer, H., Zhao, H. Y., Zuo, Y. H., and Kang, Z. S. 2009. Diversity among single zoospore isolates derived from singlezoosporangia of Phytophthora sojae Kauf. and Gerd. J. Phytopathol. 157: 181-187.

Cobb, R. C., Meentemeyer, R. K., and Rizzo, D. M. 2010. Apparent competition in canopy trees determined by pathogen transmission rather than susceptibility. Ecology 91:327-333.

Colas, V., Conrod, S., Venard, P., Keller, H., Ricci, P., and Panabieres, F. 2001. Elicitin genes expressed in vitro by certain tobacco isolates of Phytophthora parasitica are down regulated during compatible interactions. Mol. PlantMicrobe Interact. 14:326-335.

Condeso, T. E., and Meentemeyer, R. K. 2007. Effects of landscape heterogeneity on the emerging forest disease sudden oak death. J. Ecol. 95: 364-375.

Cooke, D. E. L. 2007. Tracking the sudden oak death pathogen. Mol. Ecol. 16: 3735-3736.

Cushman, J. H., and Meentemeyer, R. K. 2008. Multi-scale patterns of human activity and the incidence of an exotic forest pathogen. J. Ecol. 96: 766-776.

Davidson, J. M., Patterson, H. A., and Rizzo, D. M. 2008. Sources of inoculum for Phytophthora ramorum in a redwood forest. Phytopathology 98: 860-866.

Davidson, J. M., Patterson, H. A., Wickland, A. C., Fichtner, E. J., and Rizzo, D. M. 2011. Forest type influences transmission of Phytophthora ramorum in California oak woodlands. Phytopathology 101:492-501.

Davidson, J. M., Rizzo, D. M., Garbelotto, M., Tjosvold, S., and Slaughter, G. W. 2002. Phytophthora ramorum and sudden oak death in California: II. Transmission and survival. Pages 741-749 in: Proceedings of the fifth symposium on oak woodlands: Oaks in California's changing landscape. R. B. Standiford, D. McCreary, and K. L. Purcell, eds. General Technical Report PSW-GTR-184, U.S. Dept. Agric., Forest Service, Pacific Southwest Research Station, Albany, CA.

Davidson, J. M., Wickland, A. C., Patterson, H. A., Falk, K. R., and Rizzo, D. M. 2005. Transmission of Phytophthora ramorum in mixed-evergreen forest in California. Phytopathology 95:587-596.

De Dobbelaere, I., Vercauteren, A., Speybroeck, N., Berkvens, D., Van Bockstaele, E., Maes, M., and Heungens, K. 2010. Effect of host factors on the susceptibility of Rhododendron to Phytophthora ramorum. Plant Pathol. 59:301-312.

Denman, S., Kirk, S. A., Brasier, C. M., and Webber, J. F. 2005. In vitro leaf inoculation studies as an indication of tree foliage susceptibility to Phytophthora ramorum in the UK. Plant Pathol. 54:512-521.

DiLeo, M. V., Bostock, R. M., and Rizzo, D. M. 2009. Phytophthora ramorum does not cause physiologically significant systemic injury to California bay laurel, its primary reservoir host. Phytopathology 99: 1307-1311

DiLeo, M. V., Bostock, R. M., and Rizzo, D. M. 2014. Microclimate impacts survival and prevalence of Phytophthora ramorum in Umbellularia californica, a key reservoir host of sudden oak death in northern California forests. PLoS One 9:e98195.

Dodd, R. S., Huberli, D., Mayer, W., Harnik, T. Y., Afzal-Rafli, Z., and Garbelotto, M. 2008. Evidence for the role of synchronicity between host phenology and pathogen activity in the distribution of sudden oak death canker disease. New Phytol. 179:505-514.

Efombagn, M., Bieysse, D., Nyassé, S., and Eskes, A. 2011. Selection for resistance to Phytophthora pod rot of cocoa (Theobroma cacao L.) in Cameroon: Repeatability and reliability of screening tests and field observations. Crop Prot. 30:105-110.

Erwin, D. C., and Ribeiro, O. K. 1996. Phytophthora Diseases Worldwide. 1st ed. The American Phytopathological Society, St. Paul, MN.

Fichtner, E., Lynch, S., and Rizzo, D. 2005. Seasonal survival of Phytophthora ramorum in soils. (Abstr.) Phytopathology 95(suppl.):S29.

Filipe, J. A. N., Cobb, R. C., Meentemeyer, R. K., Lee, C. A., Valachovic, Y. S., Cook, A. R., Rizzo, D. M., and Gilligan, C. A. 2012. Landscape epidemiology and control of pathogens with cryptic and long-distance dispersal: Sudden oak death in Northern Californian forests. PLOS Comput. Biol. 8:e1002328.

Frankel, S. J. 2008. Sudden oak death and Phytophthora ramorum in the USA: A management challenge. Australas. Plant Pathol. 37:19-25. 
Garbelotto, M., and Hayden, K. J. 2012. Sudden oak death: Interactions of the exotic oomycete Phytophthora ramorum with naive North American hosts. Eukaryot. Cell 11:1313-1323.

Garbelotto, M., and Schmidt, D. J. 2009. Phosphonate controls sudden oak death pathogen for up to 2 years. Calif. Agric. 63:10-17.

Gebhardt, C., and Valkonen, J. P. 2001. Organization of genes controlling disease resistance in the potato genome. Annu. Rev. Phytopathol. 39: 79-102.

Goralka, J. L., Schumaker, M. A., and Langenheim, J. H. 1996. Variation in chemical and physical properties during leaf development in California bay tree (Umbellularia californica): Predictions regarding palatability for deer. Biochem. Syst. Ecol. 24:93-103.

Goss, E. M., Carbone, I., and Grünwald, N. J. 2009. Ancient isolation and independent evolution of the three clonal lineages of the exotic sudden oak death pathogen Phytophthora ramorum. Mol. Ecol. 18:1161-1174.

Grünwald, N. J., and Flier, W. G. 2005. The biology of Phytophthora infestans at its center of origin. Annu. Rev. Phytopathol. 43:171-190.

Grünwald, N. J., Goss, E. M., and Press, C. M. 2008. Phytophthora ramorum: A pathogen with a remarkably wide host range causing sudden oak death on oaks and Ramorum blight on woody ornamentals. Mol. Plant Pathol. 9: 729-740.

Haas, S. E., Cushman, J. M., Dillon, W. W., Rank, N. E., Rizzo, D. M., and Meentemeyer, R. K. Effects of individual, community and landscape drivers on the dynamics of a wildland forest epidemic. Ecology (in press.)

Hansen, E. M. 2008. Alien forest pathogens: Phytophthora species are changing world forests. Boreal Environ. Res. 13:33-41.

Hansen, E. M., Kanaskie, A., Prospero, S., McWilliams, M., Goheen, E. M., Osterbauer, N., Reeser, P., and Sutton, W. 2008. Epidemiology of Phytophthora ramorum in Oregon tanoak forests. Can. J. For. Research-Revue Can. De Rech. Forestiere 38:1133-1143.

Hansen, E. M., Parke, J. L., and Sutton, W. 2005. Susceptibility of Oregon forest trees and shrubs to Phytophthora ramorum: A comparison of artificial inoculation and natural infection. Plant Dis. 89:63-70.

Hoopen, G. M., Rees, R., Aisa, P., Stirrup, T., and Krauss, U. 2003. Population dynamics of epiphytic mycoparasites of the genera Clonostachys and Fusarium for the biocontrol of black pod (Phytophthora palmivora) and moniliasis (Moniliophthora roreri) on cocoa (Theobroma cacao). Mycol. Res. 107:587-596.

Huberli, D., Harnik, T. Y., Meshriy, M., Miles, L., and Garbelotto, M. 2006. Phenotypic variation among Phytophthora ramorum isolates from California and Oregon. Pages 131-134 in: Proceedings of the sudden oak death second science symposium: The state of our knowledge. General Technical Report PSW-GTR-196. S. J.Frankel, P. J. Shea, and M. I. Haverty, eds. U.S. Department of Agriculture, Forest Service, Pacific Southwest Research Station, Albany, CA.

Huberli, D., Hayden, K. J., Calver, M., and Garbelotto, M. 2012. Intraspecific variation in host susceptibility and climatic factors mediate epidemics of sudden oak death in western US forests. Plant Pathol. 61: 579-592.

Huitema, E., Bos, J. I. B., Tian, M. Y., Win, J., Waugh, M. E., and Kamoun, S. 2004. Linking sequence to phenotype in Phytophthora-plant interactions. Trends Microbiol. 12:193-200.

Huitema, E., Vleeshouwers, V. G., Cakir, C., Kamoun, S., and Govers, F. 2005. Differences in intensity and specificity of hypersensitive response induction in Nicotiana spp. by INF1, INF2A, and INF2B of Phytophthora infestans. Mol. Plant-Microbe Interact. 18:183-193.

Johnston, S. J. 2009. California bay laurel (Umbellularia californica) susceptibility to Phytophthora ramorum: Effects of tree phenology, leaf ontogeny and environmental factors. MS Thesis, Rohnert Park, Sonoma State University, California.

Judelson, H. S., and Blanco, F. A. 2005. The spores of Phytophthora; Weapons of the plant destroyer. Natl. Rev. 3:47-58.

Kamoun, S., Klucher, K. M., Coffey, M. D., and Tyler, B. M. 1993. A gene encoding a host-specific elicitor protein of Phytophthora parasitica. Mol. Plant-Microbe Interact. 6:573-581.

Kanaskie, A., Goheen, E., Hansen, E., Osterbauer, N., McWilliams, M., Schultz, R., Savona, S., Sutton, W., and Reeser, P. 2009.Early detection and eradication of Phytophthora ramorum (sudden oak death) in Oregon forests. (Abstr.) Phytopathology 99(suppl.):S61.

Kelly, M., Liu, D. S., McPherson, B., Wood, D., and Standiford, R. 2008. Spatial pattern dynamics of oak mortality and associated disease symptoms in a California hardwood forest affected by sudden oak death. J. For. Res. $13: 312-319$

Kelly, M., and Meentemeyer, R. K. 2002. Landscape dynamics of the spread of sudden oak death. Photogramm. Eng. Remote Sensing 68:1001-1009.

Kharwar, R. N., Gond, S. K., Kumar, A., and Mishra, A. 2010. A comparative study of endophytic and epiphytic fungal association with leaf of Eucalyptus citriodora Hook., and their antimicrobial activity. World J. Microbiol. Biotechnol. 26:1941-1948.
Kinkaid, C. 2005. Guidelines for selecting the covariance structure in mixed model analysis. Proceedings of the Thirtieth Annual SAS Users Group International Conference. SAS Institute, Cary, NC.

Kovacs, K., Vaclavik, T., Haight, R. G., Pang, A., Cunniffe, N. J., Gilligan, C. A., and Meentemeyer, R. K. 2011. Predicting the economic costs and property value losses attributed to sudden oak death damage in California (2010-2020). J. Environ. Manage. 92:1292-1302.

Lai, X., Cao, L., Tan, H., Fang, S., Huang, Y., and Zhou, S. 2007. Fungal communities from methane hydrate-bearing deep-sea marine sediments in South China Sea. ISME J. 1:756-762.

Le Berre, J. Y., Engler, G., and Panabieres, F. 2008. Exploration of the late stages of the tomato-Phytophthora parasitica interactions through histological analysis and generation of expressed sequence tags. New Phytol. 177:480-492.

Littell, R. C., Henry, P. R., and Ammerman, C. B. 1998. Statistical analysis of repeated measures data using SAS procedures. J. Anim. Sci. 76: 1216-1231

Liu, Z. Y., Bos, J. I. B., Armstrong, M., Whisson, S. C., da Cunha, L., Torto-Alalibo, T., Win, J., Avrova, A. O., Wright, F., Birch, P. R. J., and Kamoun, S. 2005. Patterns of diversifying selection in the phytotoxin-like scr74 gene family of Phytophthora infestans. Mol. Biol. Evol. 22: 659-672.

Mascheretti, S., Croucher, P. J. P., Kozanitas, M., Baker, L., and Garbelotto, M. 2009. Genetic epidemiology of the Sudden Oak Death pathogen Phytophthora ramorum in California. Mol. Ecol. 18:4577-4590.

McPherson, B. A., Mori, S. R., Wood, D. L., Kelly, M., Storer, A. J., Svihra, P., and Standiford, R. B. 2010. Responses of oaks and tanoaks to the sudden oak death pathogen after 8y of monitoring in two coastal California forests. For. Ecol. Manage. 259:2248-2255

McPherson, B. A., Mori, S. R., Wood, D. L., Storer, A. J., Svihra, P., Kelly, N. M., and Standiford, R. B. 2005. Sudden oak death in California: Disease progression in oaks and tanoaks. For. Ecol. Manage. 213: 71-89.

Meentemeyer, R., Rizzo, D., Mark, W., and Lotz, E. 2004. Mapping the risk of establishment and spread of sudden oak death in California. For. Ecol. Manage. 200:195-214.

Meentemeyer, R. K., Anacker, B. L., Mark, W., and Rizzo, D. M. 2008a. Early detection of emerging forest disease using dispersal estimation and ecological niche modeling. Ecol. Appl. 18:377-390.

Meentemeyer, R. K., Cunniffe, N. J., Cook, A. R., Filipe, J. A. N., Hunter, R. D., Rizzo, D. M., and Gilligan, C. A. 2011. Epidemiological modeling of invasion in heterogeneous landscapes: spread of sudden oak death in California (1990-2030). Ecosphere 2:art17.

Meentemeyer, R. K., Rank, N. E., Anacker, B. L., Rizzo, D. M., and Cushman, J. H. 2008b. Influence of land-cover change on the spread of an invasive forest pathogen. Ecol. Appl. 18:159-171.

Meentemeyer, R. K., Rank, N. E., Shoemaker, D. A., Oneal, C. B., Wickland, A. C., Frangioso, K. M., and Rizzo, D. M. 2008c. Impact of sudden oak death on tree mortality in the Big Sur ecoregion of California. Biol. Invasions 10:1243-1255.

Meshriy, M., Huberli, D., Harnik, T. Y., Miles, L., Reuther, K., and Garbelotto, M. 2006. Variation in susceptibility of Umbellularia californica (Bay Laurel) to Phytophthora ramorum. Pages 87-89 in: Proceedings of the sudden oak death second science symposium: the state of our knowledge General Technical Report PSW-GTR-196. S. J. Frankel, P. J. Shea, and M. I. Haverty, eds. U.S. Dept. Agric., Forest Service, Pacific Southwest Research Station, Albany, CA.

Metz, M. R., Frangioso, K. M., Meentemeyer, R. K., and Rizzo, D. M. 2011. Interacting disturbances: Wildfire severity affected by stage of forest disease invasion. Ecol. Appl. 21:313-320.

Metz, M. R., Frangioso, K. M., Wickland, A. C., Meentemeyer, R. K., and Rizzo, D. M. 2012. An emergent disease causes directional changes in forest species composition in coastal California. Ecosphere 3:art86.

Moser, B. E. 2004. Repeated measures modelling with Proc Mixed. Pages 9-12 in: Proceedings of the Twenty-Ninth Annual SAS Users Group International Conference. SAS Institute, Cary, NC.

Nyassé, S., Cilas, C., Herail, C., and Blaha, G. 1995. Leaf inoculation as an early screening test for cocoa (Theobroma cacao L.) resistance to Phytophthora black pod disease. Crop Prot. 14:657-663.

Ochiai, N., Yarbrough, L. D., and Parke, J. L. 2006. Two methods for distinguishing zoospores and cysts of Phytophthora ramorum. Phytopathology 96:S169-S170

Ottmann, C., Luberacki, B., Kufner, I., Koch, W., Brunner, F., Weyand, M., Mattinen, L., Pirhonen, M., Anderluh, G., Seitz, H. U., Nurnberger, T., and Oecking, C. 2009. A common toxin fold mediates microbial attack and plant defense. Proc. Natl. Acad. Sci. USA 106:10359-10364.

Pariaud, B., Ravigne, V., Halkett, F., Goyeau, H., Carlier, J., and Lannou, C. 2009. Aggressiveness and its role in the adaptation of plant pathogens. Plant Pathol. 58:409-424. 
Prospero, S., Grünwald, N. J., Winton, L. M., and Hansen, E. M. 2009. Migration patterns of the emerging plant pathogen Phytophthora ramorum on the West Coast of the United States of America. Phytopathology 99:739-749.

Prospero, S., Hansen, E. M., Grünwald, N. J., and Winton, L. M. 2007. Population dynamics of the sudden oak death pathogen Phytophthora ramorum in Oregon from 2001 to 2004. Mol. Ecol. 16:2958-2973.

Ramage, B. S., Forrestel, A. B., Moritz, M. A., and O'Hara, K. L. 2012. Sudden oak death disease progression across two forest types and spatial scales. J. Veg. Sci. 23:151-163.

Rizzo, D. M. 2006. Research on the epidemiology, ecology and management of Phytophthora ramorum in California forests. Pages 21-25 in: Proceedings of the sudden oak death second science symposium: The state of our knowledge. S. J. Frankel, P. J. Shea, and M. I. Haverty, eds. General Technical Report PSW-GTR-196. U.S. Dept. Agric., Forest Service, Pacific Southwest Research Station, Albany, CA.

Rizzo, D. M., Garbelotto, M., Davidson, J. M., Slaughter, G. W., and Koike, S. T. 2002a. Pages 733-740 in: Proceedings of the fifth symposium on oak woodlands: oaks in California's changing landscape. R. B. Standiford, D. McCreary, and K. L. Purcell, eds. General Technical Report PSW-GTR184. U.S. Dept. Agric., Forest Service, Pacific Southwest Research Station, Albany, CA.

Rizzo, D. M., Garbelotto, M., Davidson, J. M., Slaughter, G. W., and Koike, S. T. 2002b. Phytophthora ramorum as the cause of extensive mortality of Quercus spp. and Lithocarpus densiflorus in California. Plant Dis. 86:205-214.

Rizzo, D. M., Garbelotto, M., and Dodd, R. 2004. Modern molecular approaches to studying and controlling sudden oak death. In Vitro Cell. Dev. Biol. Anim. 40:19A.

Rizzo, D. M., Garbelotto, M., and Hansen, E. A. 2005. Phytophthora ramorum: Integrative research and management of an emerging pathogen in California and Oregon forests. Annu. Rev. Phytopathol. 43:309-335.

Shearer, B. L., Crane, C. E., Barrett, S., and Cochrane, A. 2007. Phytophthora cinnamomi invasion, a major threatening process to conservation of flora diversity in the South-west Botanical Province of Western Australia. Aust. J. Bot. 55:225-238.

Soanes, D. M., and Talbot, N. J. 2008. Moving targets: rapid evolution of oomycete effectors. Trends Microbiol. 16:507-510.

Tahi, G. M., Kebe, B. I., Sangare, A., Mondeil, F., Cilas, C., and Eskes, A. B. 2006. Foliar resistance of cacao (Theobroma cacao) to Phytophthora palmivora as an indicator of pod resistance in the field: interaction of cacao genotype, leaf age and duration of incubation. Plant Pathol. 55: 776-782.

Taylor, D., and Bruns, T. 1999. Community structure of ectomycorrhizal fungi in a Pinus muricata forest: Minimal overlap between the mature forest and resistant propagule communities. Mol. Ecol. 8:1837-1850.

Thaler, J. S., Owen, B., and Higgins, V. J. 2004. The role of the jasmonate response in plant susceptibility to diverse pathogens with a range of lifestyles. Plant Physiol. 135:530-538.

Tian, D., and Babadoost, M. 2004. Host range of Phytophthora capsici from pumpkin and pathogenicity of isolates. Plant Dis. 88:485-489.

Tjosvold, S. A., Chambers, D. L., Koike, S. T., and Mori, S. R. 2008. Disease on nursery stock as affected by environmental factors and seasonal inoculum levels of Phytophthora ramorum in stream water used for irrigation. Plant Dis. 92:1566-1573.

Tyler, B. M. 2002. Molecular basis of recognition between Phytophthora pathogens and their hosts. Annu. Rev. Phytopathol. 40:137-167.

Vaclavik, T., Kanaskie, A., Hansen, E. M., Ohmann, J. L., and Meentemeyer, R. K. 2010. Predicting potential and actual distribution of sudden oak death in Oregon: Prioritizing landscape contexts for early detection and eradication of disease outbreaks. For. Ecol. Manage. 260:1026-1035.

van den Berg, F., Lannou, C., Gilligan, C. A., and van den Bosch, F. 2014. Quantitative resistance can lead to evolutionary changes in traits not targeted by the resistance QTLs. Evol. Appl. 7:370-380.

Widmer, T. L., and Dodge, S. C. 2013. Can fungal epiphytes reduce disease symptoms caused by Phytophthora ramorum? Biol. Control 65:135-141. 